
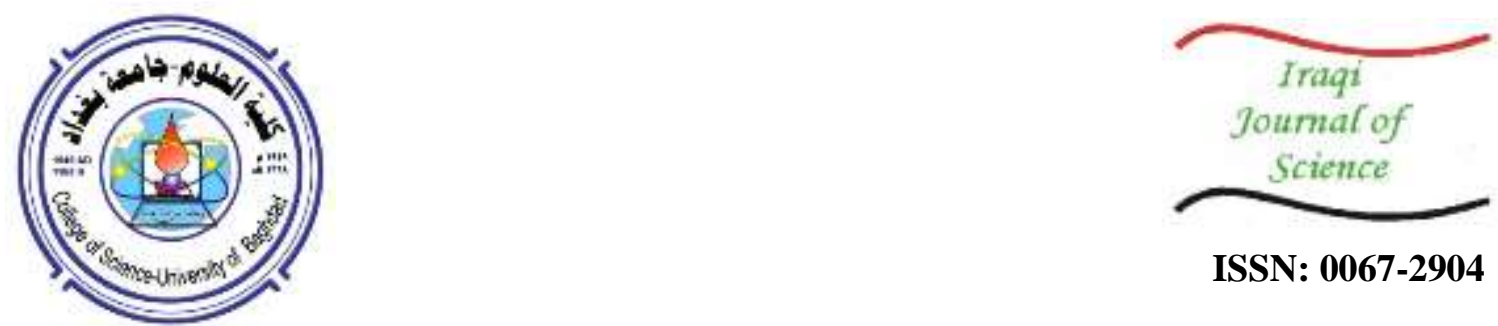

ISSN: 0067-2904

\title{
Distribution of Polycyclic Aromatic Hydrocarbons in Water and Sediments in the Euphrates River, Iraq
}

\author{
Fikrat M. Hassan*1, Abdul Hameed M.J. Al-Obaidy², Jasim M. Salman³, Sara H. \\ Abdulameer ${ }^{4}$ \\ ${ }^{1}$ Department of Biology, College of Science for Women, University of Baghdad, Iraq \\ ${ }^{2}$ Environmental Research Center, University of Technology, Baghdad, Iraq \\ ${ }^{3}$ Department of Biology, College of Science, University of Babylon, Iraq \\ ${ }^{4}$ Department of Biology, College of Education for Pure Sciences, University of Karbala, Iraq
}

Received: 1/6/2019

Accepted: $17 / 7 / 2019$

\begin{abstract}
The monitoring of lotic ecosystems is important for environmental health after war crisis. This study aimed to detect the fate of the sixteen polycyclic aromatic hydrocarbon compounds (PAHs) as priority pollutants in the water and sediment of Al-Hussainya River in Karbala Province. The results indicated that the concentrations in water samples ranged from $0.24-58.72 \eta \mathrm{g} . \mathrm{L}^{-1}$ for each of the benzo(a) pyrene and benzo(g, h, i)perylene. The concentrations in sediment samples have been observed to be in a range of 0.36-119.06 $\mu \mathrm{g} . \mathrm{g}^{-1}$ for naphthalene and benzo(g,h,i)perylene. Benzo(g,h,i)perylene recorded the highest concentrations in each of water and sediment samples as compared with the other compounds. The ratios of the specific PAH compounds were calculated to evaluate the possible sources of PAH contamination. These ratios reflected pyrogenic and petrogenic origins in both water and sediments.
\end{abstract}

Keywords: PAHs, Lotic ecosystems, Water, Sediments, Al-Hussainya River, Pyrogenic, Petrogenic.

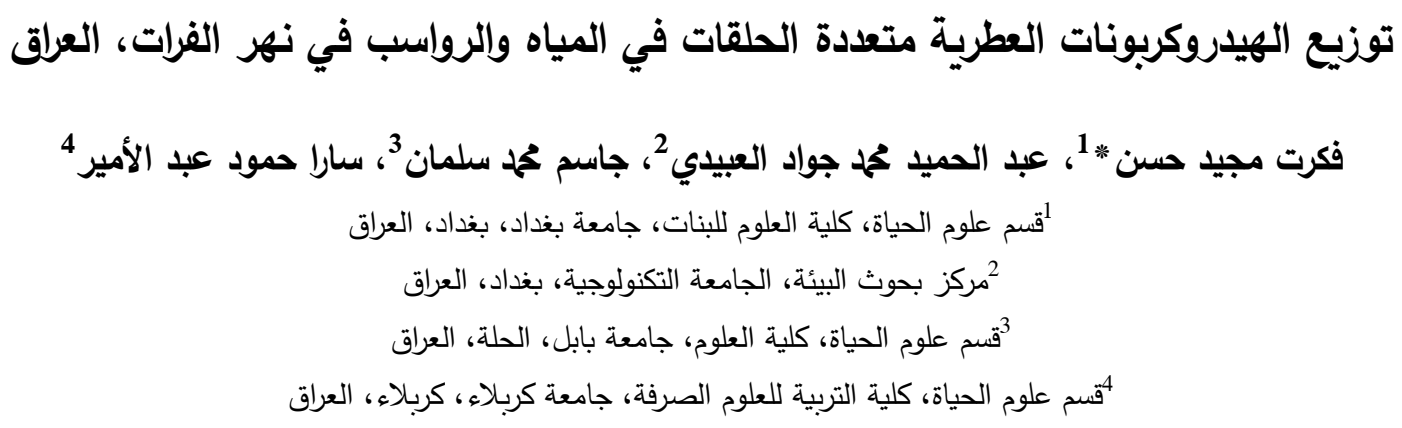

الخلاصة

تعد مراقبة النظام البيئي ضرورية للإصحاح البيئي بعد أزمات الحروب. لذا فان الدراسة الحالية تهدف

الى الكثف عن مصير ستة عشر مركب من المركبات الهيدروكربونية العطرية متعددة الحلقات باعتبارها

ملوثات ذات أولوية مهمة في مياه ورواسب نهر الحسينية في مدينة كربلاء. وقد اشارت النتائج الى ان تركيز

(benzo (g,h,l) perylene) و في نماذج المياه كان بحدود 0.24-58.72 (benzo (a) pyrene)

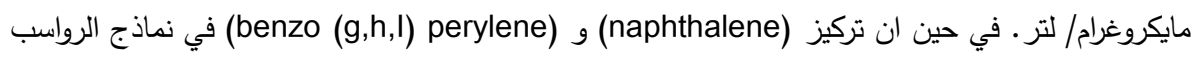

*Email: fikrat@csw.uobaghdad.edu.iq 


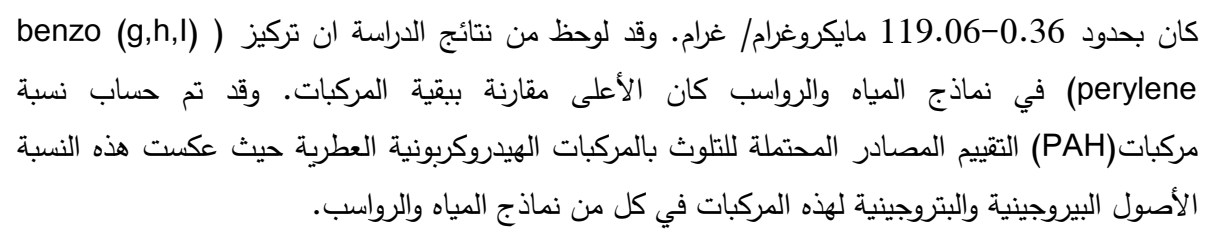

\section{Introduction}

Several decades of political and social instability in Iraq as a result of several consecutive wars led to environmental degradations as indirect effects [1]. However, little environmental policy efforts were made to remediate these issues [1]. Environmental degradation occurs due to negligence of governments to develop and enforce water and air regulations, which are detrimental to local communities [2]. In Iraq, no such major study has been performed. Hassan and his colleagues [3-8] started studying the effects of pollution in Euphrates River in the middle region of Iraq to clarify the extent of environmental degradation that occurred in Iraq and to move policy makers to take the environmental impacts of socio-political instability into account when making decisions that concern war and peace. The environmental effects are devastating, yet it is difficult to obtain critical environmental data. The organic polycyclic aromatic hydrocarbons consist only of carbon and hydrogen atoms with two rings or more $[9,10]$. PAHs are naturally produced from the combust of forests or from the volcanic activities, in addition to the fuel industrial products [11]. These compounds are generated in the aquatic ecosystems due to the municipal incomplete waste degradation and different types of fuel combustion from different industrial waste streams. Solubility of PAHs in water depends inversely on their molecular weights, whereas it has a positive relationship with other characteristics such as vapor, pressure and lipophilic features [12]. The lipophilic characteristic of PAHs is key to their impacts on the health of human and other organisms, since they can be accumulated in the adipose tissues, leading to toxic effects through carcinogenic and mutagenic reactions at the cellular level $[10,13]$.

USEPA identified the sixteen most toxic compounds of PAHs which are divided into two groups. First, the low molecular weight compounds (LMWC) (2-3 rings) that include naphthalene [Nap], acenaphthylene [Acpy], acenaphthene [Acp], fluorene [Flu], anthracene [Ant], phenanthrene [Phen], and fluoranthene [Fla]. Second, the high molecular weight compounds (HMWC) (4 or more rings) that include pyrene $[\mathrm{Py}]$, benzo(a)anthracene $[\mathrm{B}(\mathrm{a}) \mathrm{A}]$, chrysene $[\mathrm{Chry}]$, benzo(b)fluoranthene $[\mathrm{B}(\mathrm{b}) \mathrm{F}]$, benzo(k)fluoranthene $[\mathrm{B}(\mathrm{k}) \mathrm{F}]$, benzo(a)pyrene $[\mathrm{B}(\mathrm{a}) \mathrm{P}]$, dibenzo(a,h)anthracene $[\mathrm{D}(\mathrm{ah}) \mathrm{A}]$, benzo(g,h,i)perylene [B(ghi)P] and indeno(1,2,3-cd)pyrene [InP] [14].

Several studies were conducted to estimate PAH pollution in a number of aquatic ecosystems in Iraq. Mohammed et al. [4] characterized sixteen PAHs in Euphrates River, with total concentrations of $6.45 \mu \mathrm{g} / 1$ and $167 \eta \mathrm{g} / \mathrm{g}$ in water and sediment samples, respectively. HMWC were dominant in comparison to LMWC in both water and sediment samples. Hassan et al. [6] investigated the distribution of PAH compounds in water and sediment samples from Al-Hilla River, They reported that the total concentrations were $0.226 \mu \mathrm{g} /$ lin water samples, dominated by the low molecular weight Acp, and $402.54 \mu \mathrm{g} /$ gin sediment samples, dominated by the high molecular weight B(ghi)P [6].

Several studies showed that lighter PAHs dominated water samples, while heavier compounds dominated sediment samples $[6,15,16]$. In addition, the high concentrations of PAHs in riverine sediments caused by the industrial activities are not easy to remove [12]. While, other studies estimated heavy pollution from PAHs in different habitats around the world [17-19]. However, the current study aimed to identify the distribution and origin of PAH in the water and sediment of the Euphrates River (Al-Hussainya River) which represents the ultimate water resource in Karbala city, since such studies contribute to reduce the evident lack of sufficient information about such pollutants in Iraqi rivers.

\section{Materials and Methods}

\subsection{Description of the study area}

The main water resource in Karbala city is Al-Hussainya River, that branches from the Euphrates River at Al-Musayyib city (Babylon Governorate), about $30 \mathrm{~km}$ north of Karbala city (Figure-1). This river passes through many agricultural, urban, and residential areas where its waters have many uses. Six sites were selected along the river; site 1 is upstream, away of the urban area and characterized by agricultural activities. Sites 2, 3, 4 and 5 are in the urban area. Agricultural and small industrial 
activities are found on both sides of the river at sits 2, 3 and 4 . The river passes the center of the small town (site 4) and Karbala city (sites 5). Site 6 is located at the downstream (Table-1).

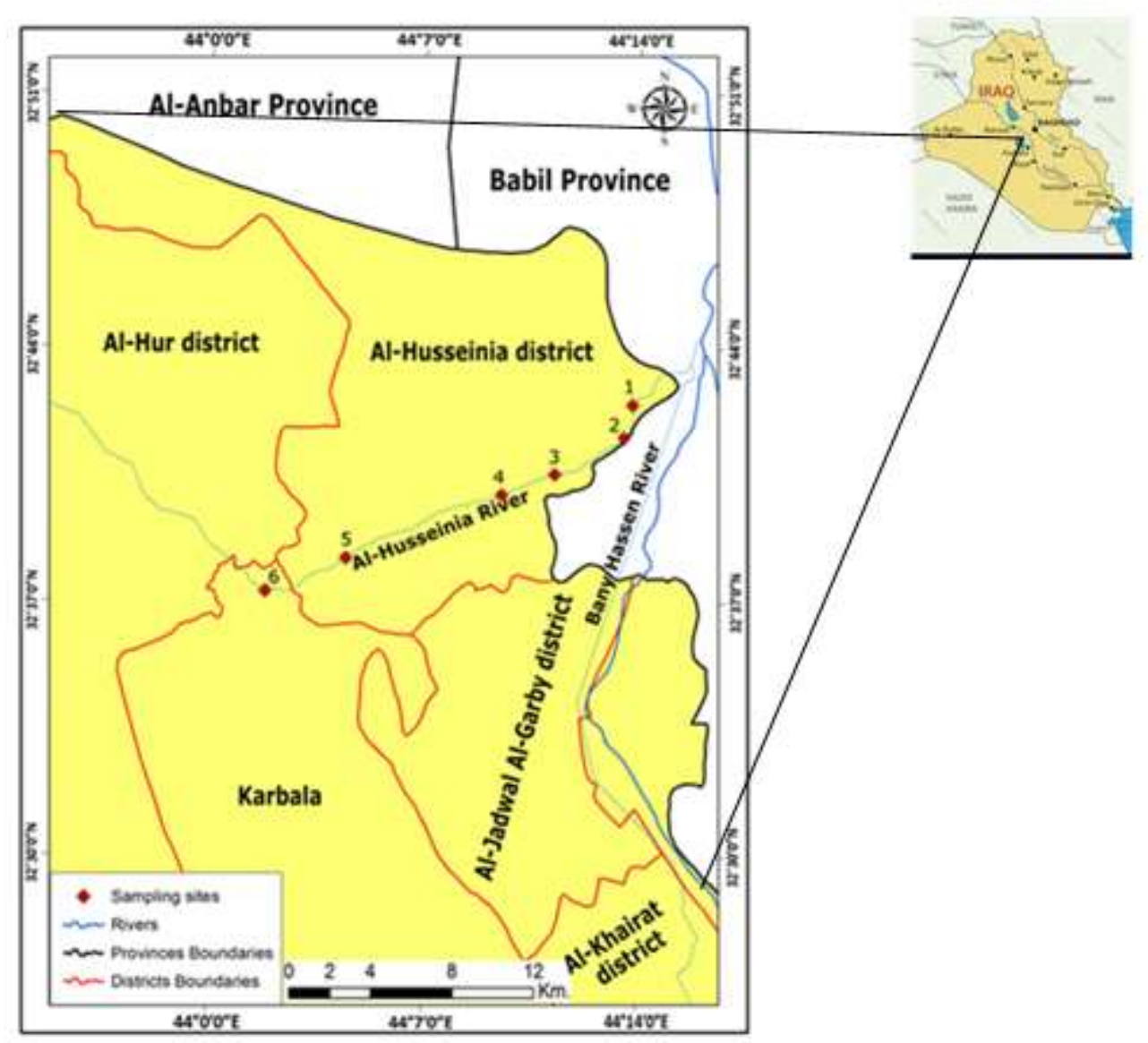

Figure 1- Map of Al-Hussainya River, middle of Iraq. Star in the inset represents the magnified map with sampling sites.

Table 1-Geographical coordinates and characteristics of the sampling sites

\begin{tabular}{cccc}
\hline Sites & Longitude (eastwards) & $\begin{array}{c}\text { Latitudes } \\
\text { (northward) }\end{array}$ & Features \\
\hline 1 & $44^{\circ} 13^{\prime} 48.00^{\prime \prime}$ & $32^{\circ} 42^{\prime} 27.00^{\prime \prime}$ & Upstream, agricultural area and away of urban area \\
2 & $044^{\circ} 13^{\prime} 31.1^{\prime \prime}$ & $32 \circ 41^{\prime} 33.0^{\prime \prime}$ & Agricultural and small industrial activities \\
3 & $044 \circ 11^{\prime} 16.1^{\prime \prime}$ & $32 \circ 40^{\prime} 32.7^{\prime \prime}$ & Agricultural and small industrial activities \\
4 & $044 \circ 09^{\prime} 32.3^{\prime \prime}$ & $32 \circ 39^{\prime} 57.4^{\prime \prime}$ & Agricultural and small industrial activities \\
5 & $044 \circ 04^{\prime} 28.3^{\prime \prime}$ & $32 \circ 38^{\prime} 12.5^{\prime \prime}$ & An urban area \\
6 & $044 \circ 01^{\prime} 50.6^{\prime \prime}$ & $32 \circ 37^{\prime} 16.8^{\prime \prime}$ & Downstream an urban area \\
\hline
\end{tabular}

The climate of the study area is semi-arid, continental, and characterizes by distinct two seasons; dry in summer and wet in winter, while spring and autumn are considered as transitional seasons. The temperature values range from $11^{\circ} \mathrm{C}$ to $50^{\circ} \mathrm{C}$ and the rainfall is limited in this area with an average of $\leq 100 \mathrm{~mm}$ [20]. The sediment of Al-Hussainya River is characterized by clay-sand mixture (the proportion of clay is 50-70\%) [21]. Physicochemical properties of the river were already studied by Hassan et al. [22]. The water was slightly alkaline to alkaline, oligohaline and very hard (Table-2). 
Table 2-Some physicochemical features of Al-Hussainya River (Following [22])

\begin{tabular}{|c|c|c|c|c|c|c|c|}
\hline \multirow{2}{*}{ Factor } & \multirow[b]{2}{*}{$\begin{array}{c}\text { Abbreviatio } \\
n\end{array}$} & \multicolumn{6}{|c|}{ Sites } \\
\hline & & 1 & 2 & 3 & 4 & 5 & 6 \\
\hline Air temperature $\left({ }^{\circ} \mathrm{C}\right)$ & AT & $22.9 \pm 7.8$ & $27.5 \pm 9.03$ & $28.8 \pm 9.4$ & $30.5 \pm 9.5$ & $31.3 \pm 9.1$ & $32.3 \pm 9$ \\
\hline Water temperature $\left({ }^{\circ} \mathrm{C}\right)$ & WT & $21.9 \pm 5.9$ & $22.2 \pm 5.6$ & $22.5 \pm 5.7$ & $22.7 \pm 5.8$ & $23 \pm 5.7$ & $23.7 \pm 5.6$ \\
\hline $\mathrm{pH}$ & $\mathrm{pH}$ & $8.06 \pm 0.32$ & $8.1 \pm 0.38$ & $8.2 \pm 0.42$ & $8.2 \pm 0.37$ & $8.3 \pm 0.45$ & $8.2 \pm 0.43$ \\
\hline $\begin{array}{l}\text { Electric Conductivity } \\
\qquad(\mu \mathrm{s} / \mathrm{cm})\end{array}$ & $\mathrm{EC}$ & $\begin{array}{c}1206.61 \pm \\
37.84\end{array}$ & $\begin{array}{c}1191.03 \pm \\
49.6\end{array}$ & $\begin{array}{c}1194.22 \pm \\
156.2\end{array}$ & $\begin{array}{c}1195.19 \pm \\
154\end{array}$ & $\begin{array}{c}1194.25 \pm \\
126.8\end{array}$ & $\begin{array}{c}1235.47 \pm \\
91.8\end{array}$ \\
\hline Salinity \%o & S\%o & $0.77 \pm 0.09$ & $0.76 \pm 0.096$ & $0.76 \pm 0.10$ & $0.76 \pm 0.097$ & $0.76 \pm 0.08$ & $0.79 \pm 0.06$ \\
\hline Water Flow cm/sec. & WF & $21.56 \pm 5.18$ & $24.72 \pm 4.15$ & $25.19 \pm 6.86$ & $22.74 \pm 4.08$ & $19.72 \pm 4.86$ & $18.76 \pm 4.85$ \\
\hline Total Alkalinity & TAlk & $\begin{array}{c}130.31 \pm \\
19.68\end{array}$ & $\begin{array}{c}128.86 \pm \\
15.34\end{array}$ & $\begin{array}{c}125.67 \pm \\
14.47\end{array}$ & $\begin{array}{c}127.53 \pm \\
13.96\end{array}$ & $\begin{array}{c}128.56 \pm \\
13.38\end{array}$ & $\begin{array}{l}126.89 \pm \\
14.56\end{array}$ \\
\hline $\begin{array}{l}\text { Dissolved Oxygen (mg } \\
\left.\mathrm{L}^{-1}\right)\end{array}$ & DO & $8.3 \pm 2.19$ & $8.12 \pm 2.05$ & $8.3 \pm 1.86$ & $8.50 \pm 1.86$ & $8.68 \pm 2.34$ & $7.84 \pm 2.33$ \\
\hline Calcium $\left(\mathrm{mg} \mathrm{L}^{-1}\right)$ & $\mathrm{Ca}$ & $\begin{array}{c}102.34 \pm \\
25.20\end{array}$ & $\begin{array}{c}100.49 \pm \\
27.02\end{array}$ & $\begin{array}{l}100.54 \pm \\
27.75\end{array}$ & $\begin{array}{l}105.21 \pm \\
25.55\end{array}$ & $94.71 \pm 23.00$ & $\begin{array}{l}101.91 \pm \\
23.84\end{array}$ \\
\hline Silica $\left(\mathrm{mg} \mathrm{L}^{-1}\right)$ & $\mathrm{SiO}_{2}$ & $4.78 \pm 0.97$ & $4.87 \pm 0.77$ & $4.66 \pm 1.08$ & $4.63 \pm 1.1$ & $4.61 \pm 0.86$ & $4.32 \pm 1.24$ \\
\hline
\end{tabular}

\subsection{Sample collection}

Samples of both water and sediment were monthly collected from six sites along Al-Hussainya River from October 2012 to September 2013. Water samples were taken at a depth of 50cmbelow the water surface by dark glass bottles $(2.5 \mathrm{~L})$ containing $60 \mathrm{ml}$ carbon tetra chloride $\left(\mathrm{CCl}_{4}\right)$ solvent. Samples were then placed in an icebox after they were wrapped with aluminum foil [23]. Sediment samples were collected using Ekman Grab sampler, placed in aluminum foil and kept at $-20^{\circ} \mathrm{C}$ prior to analysis [24].

\subsection{PAH extraction}

PAHs were extracted from water and sediment samples according to previously published methods [23,24]. Briefly, riverine water samples were separated from the organic material with $\mathrm{CCl}_{4}$ andevaporated by rotary evaporator with 9:1 acetonitrile: methanol. Sediment samples were first dried, homogenized, mixed with $25 \mathrm{ml}$ acetone and left in the dark overnight. The samples were then centrifuged and the supernatant was transferred for separation with a mixture of 1:2 hexane: deionized water. The organic fraction was stored in a 9:1 acetonitrile: methanol mixture until analyzed for PAHs by high performance liquid chromatography (HPLC). After analyzing the concentrations of individual compounds, the ratios of $\mathrm{Ant} /(\mathrm{Ant}+\mathrm{Phen})$ and $F l u r /(F l u r+P y)$ were used to determine PAH origin in water and sediment samples [11]. The $A n t /(A n t+P h e n)$ ratio is an excellent indicator for samples that have either a pyrogenic $(A n t /(A n t+P h e n)>0.1)$ or petrogenic $(A a n t /(A n t+P h e n)<0.1)$ origin. The $F l u r /(F l u r+P y)$ ratio can be used to classify the PAH source as being petroleum (ratio < 0.4 ), combustion of a liquid fossil fuel (e.g. Vehicle petrol; $0.4<F l u r /(F l u r+P y)<0.5$ ), or combustion of solid fuel (e.g., wood or coal; Flur $/(F l u r+P y)>0.5)$ [22,23].All obtained data were subjected to statistical analysis using the Statistical Package for the Social Sciences (SPSS) software (version 22).

\section{Results and Discussion}

Sixteen PAHs were identified in Al-Hussainya River water and sediment samples during this study. These compounds were selected because they are considered to be primary pollutants as described by the USEPA [13]. The results are consistent with two previous studies conducted on the Euphrates River and its branches [4,6].

\subsection{PAHs in river water}

It is critical to understand the distribution and fate of PAHs in aquatic systems, because of their toxic effects to humans and aquatic organisms $[25,26]$. The average concentration of PAHs in $\mathrm{Al}-$ 
Hussainya River water samples showed a range from $1.11 \pm 0.79 \eta \mathrm{g} . \mathrm{L}^{-1}$ at Site 1 to $56.65 \pm \eta \mathrm{g} . \mathrm{L}^{-1}$ at Site 5, recorded for $\mathrm{B}(\mathrm{a}) \mathrm{P}$ and $\mathrm{B}(\mathrm{ghi}) \mathrm{P}$, respectively (Table-3). However, concentrations in water samples showed a pattern of greater concentrations for the lower molecular weight compounds, except for the high molecular weight $\mathrm{B}(\mathrm{ghi}) \mathrm{P}$ which was also found in higher concentrations.

The elevated levels of $\mathrm{B}(\mathrm{ghi}) \mathrm{P}$ may be the result of increased vehicle and boat exhaust materials deposited into the river [27]. The HMWCs (4-6 rings) had lower concentrations than the LMWCs, except for $\mathrm{B}(\mathrm{ghi}) \mathrm{P}$, which may be high despite their decreased solubility in water and their lipophilic and hydrophobic properties. Similar results were previously found in Al-Hilla River [6] but not in the Klang Strait [28]. Based on the relationship between the calculated ratios and the origin of PAHs [28], it can be implied that the present results reveal a consistent pyrogenic origin; the ratio for Site $1(0.52)$ reveals combustion of wood or kerosene, whereas the remaining five sites show combustion of vehicle fuel (Table-4). The high level of human activities and the resultant pollution deposition of gasoline and diesel exhaust might have led to the high concentrations of $\mathrm{B}(\mathrm{ghi}) \mathrm{P}$ along the riverine environment [29]. The total PAH concentrations during this study ranged between 135.5 and 162.06 $\eta \mathrm{g} / \mathrm{l}$ in sites 2 and 5, respectively. The higher concentrations at site 5 might be due to lower water volume and flow rate, a similar pattern as that observed in Al-Hilla River [6]. In addition, the higher concentrations in water samples at Site 5 might be due to the cumulative effect of PAH release from the sediments and emissions from vehicle exhausts $[29,30]$. Values from the present study were higher than those of Mohammed et al. [4] in Euphrates River and Al-Azawey et al. [8] in Al-Hilla River. However, our results were comparably close to those of Kafilzadeh et al. [16] in Kor River, Iran. High PAHs in the Kor River were attributed to possibly high volume of traffic and human activities on both sides of the river,low water levels, and the absence of vegetation on the river banks, which exposes the river directly to land-based and atmospheric pollutants that dissolve in river water $[15,16,31]$. In addition, the presence of diesel-powered pumps used for farmland irrigation along the river may cause leakage of diesel directly into the river water. In general, petroleum products are regularly dumped into the river as a result of the lack of environmental awareness and education. Many studies attribute water pollution to vehicle exhausts, drainage of untreated sewage, municipal and industrial wastes where PAHs are dumped directly into the river, as well as agricultural activities [15,31,32]. It is observed that most of the recorded concentrations of PAH compounds are well above the current recommended values [33].

Table 3-The concentration of PAH compounds in the water samples $\left(\eta \mathrm{g} \mathrm{L}^{-1}\right)$ during study periods. First line (The range) and second line (The average \pm S.D.)

\begin{tabular}{|c|c|c|c|c|c|c|c|}
\hline \multirow[b]{2}{*}{$\begin{array}{c}\text { PAH } \\
\text { compounds }\end{array}$} & \multicolumn{7}{|c|}{ Sites } \\
\hline & Site 1 & Site 2 & Site 3 & Site 4 & Site 5 & Site 6 & Average \\
\hline Nap & $\begin{array}{c}12.98-22.59 \\
19.27 \pm 3.9\end{array}$ & $\begin{array}{l}10.77-0.68 \\
15.88 \pm 3.71\end{array}$ & $\begin{array}{c}11.37-23.61 \\
19.28 \pm 4.91\end{array}$ & $\begin{array}{l}15.86-8.42 \\
23.39 \pm 5.03\end{array}$ & $\begin{array}{l}11.6-21.24 \\
17.89 \pm 3.89\end{array}$ & $\begin{array}{c}14.51-24.99 \\
21.23 \pm 4.17\end{array}$ & 19.49 \\
\hline AcpY & $\begin{array}{c}1.81-3.42 \\
2.5 \pm 0.7\end{array}$ & $\begin{array}{l}2.51-3.97 \\
3.11 \pm 0.62\end{array}$ & $\begin{array}{c}1.2-1.93 \\
1.65 \pm 0.31\end{array}$ & $\begin{array}{c}2.5-4.59 \\
3.47 \pm 0.89\end{array}$ & $\begin{array}{l}3.18-3.95 \\
3.57 \pm 0.40\end{array}$ & $\begin{array}{l}2.48-3.85 \\
3.12 \pm 0.53\end{array}$ & 2.9 \\
\hline Acp & $\begin{array}{c}22.89-28.26 \\
25.7 \pm 2.43\end{array}$ & $\begin{array}{c}16.71-26.58 \\
20.92 \pm 4.17\end{array}$ & $\begin{array}{c}32.43-38.85 \\
36.8 \pm 2.67\end{array}$ & $\begin{array}{l}32.02-43.8 \\
40.24 \pm 4.99\end{array}$ & $\begin{array}{l}27.03-0.62 \\
35.03 \pm 5.2\end{array}$ & $\begin{array}{c}30.56-40.08 \\
33.96 \pm 3.84\end{array}$ & 32.11 \\
\hline Flu & $\begin{array}{c}13.75-22.81 \\
18.86 \pm 4.2\end{array}$ & $\begin{array}{l}4.26-21.98 \\
12.69 \pm 7.71\end{array}$ & $\begin{array}{l}1.92-22.45 \\
11.41 \pm 8.56\end{array}$ & $\begin{array}{l}7.04-21.93 \\
13.54 \pm 5.77\end{array}$ & $\begin{array}{l}10.71-0.11 \\
15.13 \pm 3.55\end{array}$ & $\begin{array}{l}7.52-21.58 \\
14.48 \pm 6.57\end{array}$ & 14.35 \\
\hline Phen & $\begin{array}{l}1.82-2.47 \\
2.14 \pm 0.32\end{array}$ & $\begin{array}{l}2.90-3.43 \\
3.16 \pm 0.28\end{array}$ & $\begin{array}{l}1.41-3.65 \\
2.65 \pm 0.84\end{array}$ & $\begin{array}{l}1.97-4.52 \\
3.34 \pm 1.05\end{array}$ & $\begin{array}{l}2.23-3.26 \\
2.83 \pm 0.43\end{array}$ & $\begin{array}{l}1.46-4.31 \\
3.04 \pm 1.08\end{array}$ & 2.86 \\
\hline Ant & $\begin{array}{l}1.99-3.42 \\
2.72 \pm 0.56\end{array}$ & $\begin{array}{l}1.67-3.33 \\
2.6 \pm 0.65\end{array}$ & $\begin{array}{l}1.26-4.09 \\
2.85 \pm 1.08\end{array}$ & $\begin{array}{l}1.21-3.81 \\
2.39 \pm 1.05\end{array}$ & $\begin{array}{l}0.51-3.61 \\
2.23 \pm 1.24\end{array}$ & $\begin{array}{l}0.84-3.93 \\
2.48 \pm 1.24\end{array}$ & 2.55 \\
\hline Fla & $\begin{array}{l}1.62-3.44 \\
2.63 \pm 0.76\end{array}$ & $\begin{array}{c}1.6-3.1 \\
2.71 \pm 0.88\end{array}$ & $\begin{array}{l}1.68-2.78 \\
2.13 \pm 0.52\end{array}$ & $\begin{array}{l}2.04-4.36 \\
3.22 \pm 0.87\end{array}$ & $\begin{array}{l}2.03-3.45 \\
2.77 \pm 0.55\end{array}$ & $\begin{array}{l}1.92-3.29 \\
2.61 \pm 0.57\end{array}$ & 2.68 \\
\hline $\mathbf{P y}$ & $2.43 \pm 0.75$ & $3.46 \pm 0.77$ & $2.88 \pm 0.85$ & $4.01 \pm 0.42$ & $4.74 \pm 0.74$ & $4.11 \pm 1.09$ & 3.62 \\
\hline
\end{tabular}




$\begin{array}{cccccccc}\text { Py } & 1.73-3.25 & 2.47-4.21 & 1.69-3.74 & 3.48-4.47 & 3.69-4.91 & 2.73-4.82 & 4.62 \\ & 2.43 \pm 0.76 & 3.46 \pm 0.78 & 2.88 \pm 0.86 & 4.01 \pm 0.43 & 4.74 \pm 0.75 & 4.11 \pm 1.10 & \\ \text { B(a)A } & 4.1-5.95 & 4.73-6.49 & 2.37-5.22 & 1.64-4.58 & 1.02-5.24 & 3.31-6.05 & 4.53 \\ & 4.96 \pm 0.84 & 5.7 \pm 0.75 & 3.99 \pm 1.09 & 3.56 \pm 1.19 & 3.79 \pm 1.72 & 5.1 \pm 1.1 & \\ \text { Chry } & 4.1-5.95 & 4.73-6.49 & 2.37-5.22 & 1.64-4.58 & 1.02-5.24 & 3.31-6.05 & 3.02 \\ & 2.83 \pm 0.97 & 2.42 \pm 0.76 & 2.7 \pm 0.81 & 3.45 \pm 0.85 & 3.32 \pm 1.29 & 3.42 \pm 1.07 & \\ \text { B(b)F } & 1.58-2.56 & 1.94-2.91 & 1.31-2.42 & 1.88-3.58 & 2.1-3.17 & 1.97-3.87 & 2.45 \\ & 2.11 \pm 0.48 & 2.42 \pm 0.49 & 1.8 \pm 0.53 & 2.56 \pm 0.67 & 2.73 \pm 0.42 & 3.07 \pm 0.77 & \\ \text { B(k)F } & 3.37-4.89 & 2.86-4.75 & 1.46-5.11 & 3.62-5.33 & 3.36-5.64 & 4.33-6.09 & 4.44 \\ & 4.27 \pm 0.61 & 3.74 \pm 0.8 & 3.64 \pm 1.41 & 4.72 \pm 0.7 & 4.9 \pm 0.97 & 5.35 \pm 0.73 & \\ \text { B(a)P } & 0.36-2.37 & 0.54-2.21 & 0.51-2.15 & 0.35-2.67 & 0.32-2.18 & 0.24-2.5 & 1.26 \\ & 1.11 \pm 0.79 & 1.17 \pm 0.65 & 1.18 \pm 0.67 & 1.37 \pm 0.97 & 1.39 \pm 0.7 & 1.37 \pm 0.9 & \\ \text { DbA } & 1.5-2.54 & 1.3-1.76 & 1.57-3.28 & 1.61-2.95 & 2.05-4.69 & 2.14-3.51 & 2.38 \\ & 1.89 \pm 0.43 & 1.63 \pm 0.23 & 2.39 \pm 0.65 & 2.38 \pm 0.53 & 3.12 \pm 1.04 & 2.84 \pm 0.56 & \\ \text { B(ghi)P } & 49.43-53.87 & 41.28-57.02 & 45.51-52.76 & 37.69-2.67 & 52.29-8.72 & 38.42-54.93 & 51.61 \\ & 52.42 \pm 2.31 & 52.49 \pm 6.92 & 50.18 \pm 3.19 & 48.32 \pm 6.57 & 56.65 \pm 2.98 & 49.63 \pm 7.11 & \\ \text { InP } & 0.65-1.83 & 0.44-1.90 & 1.27-2.56 & 1.23-2.38 & 1.48-2.5 & 1.32-2.42 & 1.72 \\ \text { Total PAHs } & 1.29 \pm 0.51 & 1.3 \pm 0.61 & 2 \pm 0.54 & 1.84 \pm 0.45 & 1.98 \pm 0.5 & 1.93 \pm 0.48 & \end{array}$

Table 4-Mean ratios of individual PAHs in water samples

\begin{tabular}{ccc}
\hline Station & Ant/(Ant+Phen) & Fla/(Fla + Py $)$ \\
\hline 1 & 0.56 & 0.52 \\
2 & 0.451 & 0.439 \\
3 & 0.518 & 0.425 \\
4 & 0.417 & 0.445 \\
6 & 0.441 & 0.369 \\
\hline
\end{tabular}

For seasonal comparison (Figure-2A), three PAH compounds(Nap, Flur and DbA) recorded the lowest values in summer at site 2, while the highest values were recorded for Flu (site1), B(b)F (site 6), $\mathrm{B}(\mathrm{k}) \mathrm{F}$ (site 6), $\mathrm{B}(\mathrm{a}) \mathrm{P}$ (site 4) and $\mathrm{B}$ (ghi) $\mathrm{P}$ (site 5). In autumn, the following compounds showed the lowest values: Acp (at site 2), Flu, Phen, Py, B(k)F (site 3), B(b)F, B(ghi)P (site 4), Ant, B(a)A, Chrya (site 5), and $\mathrm{B}(\mathrm{a}) \mathrm{P}$ (site 6). The highest values in autumn were observed for AcpY, Flur (site 4) and DbA (site 5). Only two lowest values were recorded in winter: for IND (site 2) and AcpY (site3), while the highest values were recorded for B(a)A (site 2), Nap and Acp (site 4). PAH compounds that recorded highest values in spring include Ant, IND (site 3), Phen (site 4), Py and Chry (site 5). The temporal variations of these compounds are related to their source activates and the seasonal changes in physicochemical properties of the river [6,33]. 

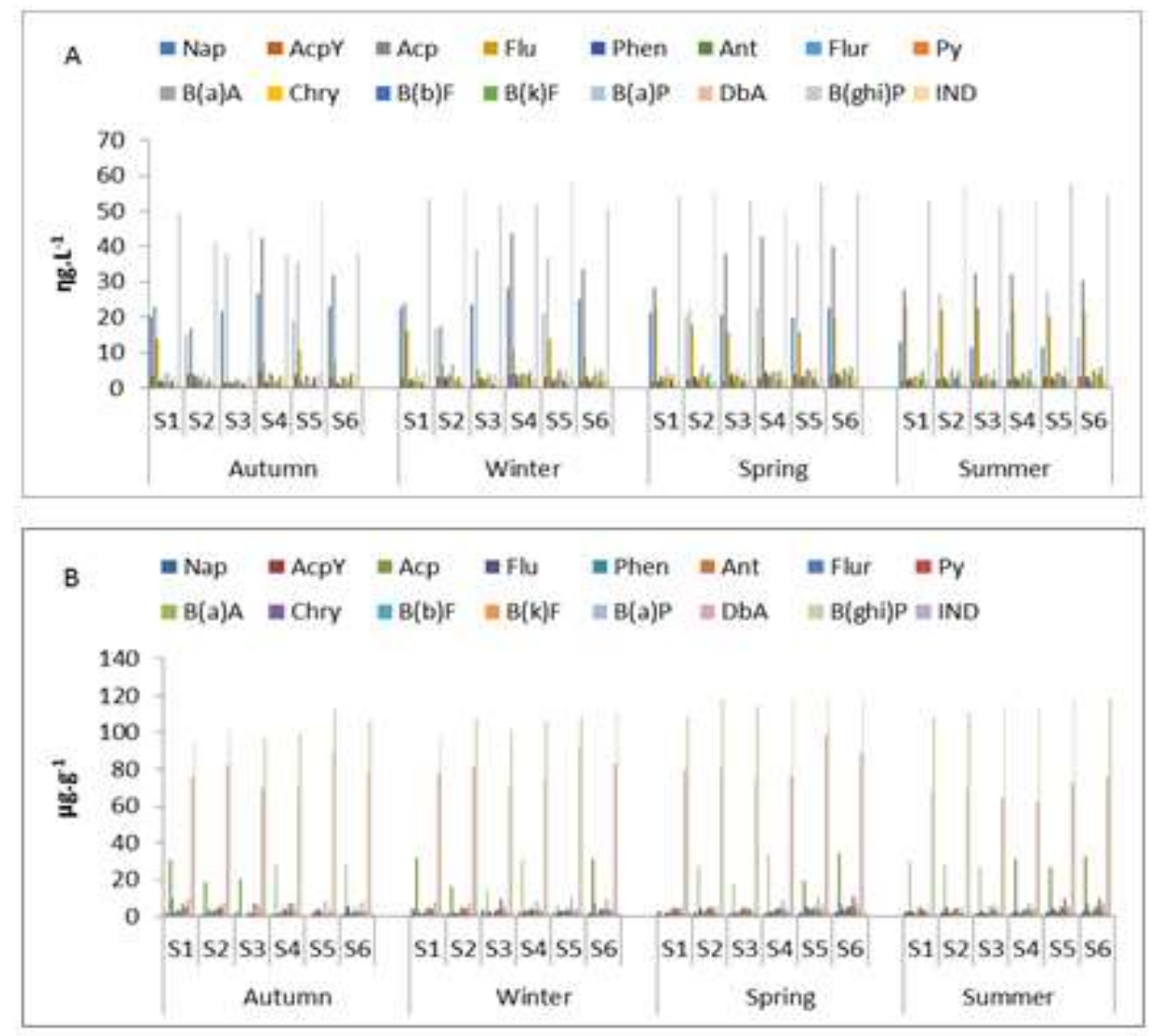

Figure 2-Seasonal variation of PAH concentrations in the water samples (A) and sediment (B) during the study periods

\subsection{PAHs in the sediments}

Riverbed sediments are an important historical indicator of water pollution in that particular river and the surrounding watershed over time, considering that the sink of most pollutants is the sediment, which has impacts on the life of benthic communities [11]. PAHs enter the sediments by adhering to sedimentary particles. Sediments also act as a source of certain pollutants that reenter the water column based on individual fraction physicochemical properties and environmental conditions [31]. Concentrations in sediment samples showed a pattern of greater concentrations for the lower molecular weight compounds, with B (ghi) Pis being an exception as a HMW compound found in higher concentrations. Furthermore, in this study, mean concentrations of PAHs in Al-Hussainya River sediments ranged between $1.70 \pm 0.85$ to $114.40 \pm 4.59 \mu \mathrm{g} \cdot \mathrm{g}^{-1}$ for Nap and B(ghi)P, respectively (Table-5). B(ghi)P also dominated the sediments of Al-Hilla River, another tributary of the Euphrates River [6]. The results revealed a dominance of HMW over the LMW compounds, which might be due to the physicochemical properties that allow HMWCs to persist in the sediments, whereas LMWCs were more prominent in the river water samples, likely due to a greater propensity to dissolve in water. The properties that allow HMWCs to persist in sediments include: (a) low solubility and lipophilic and hydrophobic properties that increase as their molecular weight increases; (b) HMWCs tend to bind to organic and sediment particles; (c)HMWCs are characterized by their stability and resistance to biodegradation processes by microorganisms as compared to LMWCs [33]. Several studies confirmed that HMWCs tend to dominate sediment contaminants $[4,16]$. The results show that the concentrations were consistent among sampling sites, indicative of similar human activities along the stretch of the river. 
Table 5-The concentration of PAHs compounds in the sediment samples $\left(\mathrm{ng} \mathrm{g}^{-1}\right)$ during study periods first line (The range) and second line (The average \pm S.D.)

\begin{tabular}{|c|c|c|c|c|c|c|c|}
\hline \multirow{2}{*}{$\begin{array}{l}\text { PAHs } \\
\text { compounds }\end{array}$} & \multicolumn{6}{|c|}{ Sites } & \multirow{2}{*}{ Average } \\
\hline & Site 1 & Site 2 & Site 3 & Site 4 & 5 Site & Site 6 & \\
\hline Nap & $\begin{array}{l}2.28-4.51 \\
3.16 \pm 0.87\end{array}$ & $\begin{array}{c}1.1-2.71 \\
1.86 \pm 0.63\end{array}$ & $\begin{array}{c}2-3.98 \\
2.8 \pm 0.76\end{array}$ & $\begin{array}{c}1.31-2.93 \\
2 \pm 0.63\end{array}$ & $\begin{array}{l}0.84-2.62 \\
2.05 \pm 0.74\end{array}$ & $\begin{array}{l}0.36-2.5 \\
1.7 \pm 0.85\end{array}$ & 2.26 \\
\hline AcpY & $\begin{array}{l}1.5-2.38 \\
1.75 \pm 0.4\end{array}$ & $\begin{array}{c}1-2.46 \\
1.6 \pm 0.57\end{array}$ & $\begin{array}{l}0.87-2.06 \\
1.33 \pm 0.49\end{array}$ & $\begin{array}{l}1.24-2.57 \\
1.77 \pm 0.56\end{array}$ & $\begin{array}{c}0.84-2.82 \\
1.8 \pm 0.78\end{array}$ & $\begin{array}{l}1.65-2.93 \\
2.26 \pm 0.55\end{array}$ & 1.75 \\
\hline Acp & $\begin{array}{l}29.71-31.81 \\
30.64 \pm 0.98\end{array}$ & $\begin{array}{c}16.39-27.73 \\
22.54 \pm 5.46\end{array}$ & $\begin{array}{c}14.8-6.98 \\
19.91 \pm 4.71\end{array}$ & $\begin{array}{l}27.77-33.49 \\
30.75 \pm 2.23\end{array}$ & $\begin{array}{c}0.84-30.34 \\
13.52 \pm 10.86\end{array}$ & $\begin{array}{c}28.61-34.9 \\
31.91 \pm 2.4\end{array}$ & 24.9 \\
\hline Flu & $\begin{array}{c}28.61-34.9 \\
31.91 \pm 2.4\end{array}$ & $\begin{array}{l}0.94-4.89 \\
3.25 \pm 1.67\end{array}$ & $\begin{array}{l}0.79-3.14 \\
2.37 \pm 1.03\end{array}$ & $\begin{array}{l}1.02-3.16 \\
2.43 \pm 0.97\end{array}$ & $\begin{array}{l}1.85-4.92 \\
3.74 \pm 1.37\end{array}$ & $\begin{array}{c}5.83-7.58 \\
7 \pm 0.77\end{array}$ & 3.94 \\
\hline Phen & $\begin{array}{c}5.83-7.58 \\
7 \pm 0.77\end{array}$ & $\begin{array}{l}1.47-3.66 \\
1.81 \pm 0.04\end{array}$ & $\begin{array}{l}0.51-1.98 \\
1.15 \pm 0.62\end{array}$ & $\begin{array}{l}1.93-2.36 \\
2.14 \pm 0.08\end{array}$ & $\begin{array}{c}3.24-4.88 \\
3.84 \pm 0.7\end{array}$ & $\begin{array}{l}0.94-4.04 \\
2.49 \pm 1.27\end{array}$ & 2.26 \\
\hline Ant & $\begin{array}{l}1.75-3.24 \\
2.34 \pm 0.65\end{array}$ & $\begin{array}{l}1.98-3.16 \\
2.56 \pm 0.54\end{array}$ & $\begin{array}{l}1.51-2.92 \\
2.1 \pm 0.65\end{array}$ & $\begin{array}{l}2.34-4.5 \\
3.4 \pm 1.02\end{array}$ & $\begin{array}{c}3.12-3.65 \\
3.47 \pm 0.4\end{array}$ & $\begin{array}{l}1.94-3.32 \\
2.62 \pm 0.68\end{array}$ & 2.75 \\
\hline $\mathrm{Fla}$ & $\begin{array}{l}2.06-3.81 \\
2.84 \pm 0.76\end{array}$ & $\begin{array}{l}2.06-3.81 \\
2.84 \pm 0.76\end{array}$ & $\begin{array}{l}2.12-3.26 \\
2.91 \pm 0.58\end{array}$ & $\begin{array}{l}3.42-4.93 \\
4.12 \pm 0.66\end{array}$ & $\begin{array}{c}2.7-4.57 \\
4.12 \pm 0.66\end{array}$ & $\begin{array}{c}2.7-4.57 \\
4.12 \pm 0.66\end{array}$ & 3.33 \\
\hline Py & $\begin{array}{c}2.7-4.57 \\
4.12 \pm 0.66\end{array}$ & $\begin{array}{c}3.24-4.99 \\
4.5 \pm 0.86\end{array}$ & $\begin{array}{c}1.98-5 \\
3.91 \pm 1.34\end{array}$ & $\begin{array}{c}1.98-5 \\
3.91 \pm 1.34\end{array}$ & $\begin{array}{l}3.32-5.4 \\
4.68 \pm 0.9\end{array}$ & $\begin{array}{l}2.21-5.74 \\
4.33 \pm 1.45\end{array}$ & 4.35 \\
\hline $\mathrm{B}(\mathrm{a}) \mathrm{A}$ & $\begin{array}{l}4.14-6.82 \\
5.11 \pm 1.15\end{array}$ & $\begin{array}{l}4.17-5.29 \\
4.58 \pm 0.48\end{array}$ & $\begin{array}{l}4.17-5.29 \\
4.58 \pm 0.48\end{array}$ & $\begin{array}{l}1.82-4.87 \\
3.82 \pm 1.28\end{array}$ & $\begin{array}{l}1.47-5.08 \\
3.78 \pm 1.51\end{array}$ & $\begin{array}{c}2.85-5.59 \\
4.51 \pm 1.1\end{array}$ & 4.22 \\
\hline Chry & $\begin{array}{c}3.82-6.57 \\
4.88 \pm 1.1\end{array}$ & $\begin{array}{c}4.6-5.44 \\
4.93 \pm 0.39\end{array}$ & $\begin{array}{l}4.25-9.45 \\
6.86 \pm 1.96\end{array}$ & $\begin{array}{c}6.93-9.35 \\
8.12 \pm 0.9\end{array}$ & $\begin{array}{c}8.36-10.65 \\
9.77 \pm 0.97\end{array}$ & $\begin{array}{l}7.09-11.22 \\
9.45 \pm 1.57\end{array}$ & 7.33 \\
\hline $\mathrm{B}(\mathrm{b}) \mathrm{F}$ & $\begin{array}{c}2.85-4.9 \\
3.51 \pm 0.85\end{array}$ & $\begin{array}{c}2.85-4.9 \\
3.51 \pm 0.85\end{array}$ & $\begin{array}{c}1.27-3.72 \\
2.84 \pm 1\end{array}$ & $\begin{array}{c}3.17-3.73 \\
3.41 \pm 0.23\end{array}$ & $\begin{array}{l}3.17-3.73 \\
3.41 \pm 0.23\end{array}$ & $\begin{array}{l}2.39-4.32 \\
3.51 \pm 0.74\end{array}$ & 3.1 \\
\hline $\mathrm{B}(\mathrm{k}) \mathrm{F}$ & $\begin{array}{c}5.3-9.51 \\
6.96 \pm 1.82\end{array}$ & $\begin{array}{c}5.3-9.51 \\
6.96 \pm 1.82\end{array}$ & $\begin{array}{c}4.99-6.27 \\
5.6 \pm 0.5\end{array}$ & $\begin{array}{c}5.2-7.57 \\
5.93 \pm 1\end{array}$ & $\begin{array}{c}5.11-6.2 \\
5.71 \pm 0.45\end{array}$ & $\begin{array}{l}3.74-8.84 \\
6.62 \pm 1.96\end{array}$ & 6.23 \\
\hline $\mathrm{B}(\mathrm{a}) \mathrm{P}$ & $\begin{array}{l}1.31-2.18 \\
1.73 \pm 0.41\end{array}$ & $\begin{array}{l}1.22-1.92 \\
1.56 \pm 0.32\end{array}$ & $\begin{array}{l}1.93-3.42 \\
2.73 \pm 0.56\end{array}$ & $\begin{array}{l}2.15-3.22 \\
2.74 \pm 0.43\end{array}$ & $\begin{array}{c}2.58-3.82 \\
3.2 \pm 0.47\end{array}$ & $\begin{array}{c}2.4-4.09 \\
3.21 \pm 0.65\end{array}$ & 2.53 \\
\hline $\mathrm{DbA}$ & $\begin{array}{l}67.69-79.82 \\
75.37 \pm 4.93\end{array}$ & $\begin{array}{c}69.35-82.38 \\
78.3 \pm 5.64\end{array}$ & $\begin{array}{l}64.92-5.06 \\
70.29 \pm 3.98\end{array}$ & $\begin{array}{l}62.48-76.21 \\
70.77 \pm 5.49\end{array}$ & $\begin{array}{c}73.5-98.56 \\
88.46 \pm 9.72\end{array}$ & $\begin{array}{l}75.66-88.8 \\
81.46 \pm 5.32\end{array}$ & 77.44 \\
\hline B(ghi)P & $\begin{array}{l}94.75-08.56 \\
102.39 \pm 6.69\end{array}$ & $\begin{array}{c}101.25- \\
117.93 \\
109.4 \pm 6.58\end{array}$ & $\begin{array}{l}96.7-114.5 \\
106.8 \pm 8.36\end{array}$ & $\begin{array}{l}99.38-17.84 \\
109.13 \pm 7.36\end{array}$ & $\begin{array}{c}108.81-118.82 \\
114.4 \pm 4.59\end{array}$ & $\begin{array}{c}106.61- \\
119.06 \\
113.92 \pm 5.94\end{array}$ & 109.34 \\
\hline
\end{tabular}

The results showed that the source of PAH pollution in the sediment was pyrogenic in origin as a result of thermal decomposition of organic matter and the burning of fossil fuels, in addition to contaminants originating from oil derivatives [11] (Table-6). The source of this pollution is attributed to high traffic density, continuous incineration of waste material, and the effect of human and agricultural activities, including diesel-burning pumps that pump water for irrigation of agricultural lands lining the riverbanks. The mechanisms that draw the pollutants into the river and then into the sediments are through to include runoff into the catchment area from wind and rain as well as the role of industry, agriculture and other human activities [4,15,19,31]. Based on the total concentration of PAHs, the sediments can be classified as being highly polluted [34].

For seasonal comparison (Figure-2B), the results indicated that Flur (site 2), DbA (site 4) and Chry (site 1) recorded the lowest values during summer. While AcpY recorded the highest values at site 6. The lowest values in autumn were recorded for Nap (site 6), AcpY, B (a)A, B (b) F at (site 5), Flu, Phen, Ant, Py, IND(site 3), B(a)P (site 2) and B(ghi) P (site 1). The highest values in autumn were recorded for Flu, B (a) A, B (k) F, B (b)F (site 1) and Flur at site 4. The lowest values were recorded 
in winter for Acp (site 5) and B (k)F (site 6), while the highest values were recorded for a Nap (site 1), $\mathrm{B}$ (a) $\mathrm{P}$ (site 6) and IND at site 3 . Seven compounds recorded the highest values in spring, as follows: Acp, Py, Chry, and B (ghi) P at site 6, Phen, DbA at site 5 and Ant at site 4. This temporal variation was caused by the different seasonal climate change, the quantity and quality of pollution sources, the rate of decomposition and accumulation by microorganisms, and, moreover, the total organic carbon contents in sediment $[4,8]$.

Table 6-Mean ratios of individual PAH compounds in sediment samples.

\begin{tabular}{ccc}
\hline Station & Ant/(Ant+Phen) & Fla/(Fla + Py) \\
\hline 1 & 0.589 & 0.395 \\
2 & 0.684 & 0.355 \\
3 & 0.646 & 0.427 \\
4 & 0.614 & 0.487 \\
5 & 0.475 & 0.468 \\
6 & 0.513 & 0.492 \\
\hline
\end{tabular}

\section{Conclusions}

Lack of environmental regulations reflected in the traffic congestion as well as agricultural and other human activities along Al-Hussainya River are the main sources of PAH pollution.

$\square$ Low molecular weight PAH's concentrations were found in high values, while the other PAH (high molecular weight) fractions existed in the sediments.

$\square$ The higher concentration of Benzo(ghi)perylene were observed in both water and sediment samples in comparison with the other compounds of PAHs.

The results indicated that PAHs are consistently found in high concentrations in Al-Hussainya River, which would lead to classify it as being highly polluted.

The origin of PAHs pollution in Al-Hussainya River is pyrogenic.

\section{References}

1. UNEP, 2003. (United Nations Environmental Program), Desk Study on the Environment in Iraq. ISBN: 92-1-158628-3 (2003) pp.98.

2. Ogbija, T.E., Atubi, A.O. and Ojeh, V.N. 2015. Effects of Environmental Degradation on Human Health in Selected Oil Communities in Delta State. J. Environ. Earth Sci, 5(9): 72-88.

3. Hassan, F.M. 2004. Effect of Aggression and Blockade on the Ecological Living Components in Iraq. National Journal of Chemistry, 14: 224-233.

4. Mohammed, A.B., Al-Taee, M.M.S., F.M. Hassan, F.M. 2009. The Study of some PAHs Compounds in Euphrates River Sediment from Al-Hindiya Barrage to Al-Kifil city, Iraq. $4^{\text {th }}$ Scientific Conference, College of Science, Babylon University. CSASC English Ver. 4(2009): 216-230.

5. Hassan, F.M., Salman, J.M., Dou Abul, A.A., Naji, A.S. 2016. Polycyclic Aromatic Hydrocarbon (PAHs) Concentrations in Some Aquatic Macrophytes in Hilla River, Iraq, Journal of Environmental Protection, 7(2): 198-211.https://doi.org/10.4236/jep.2016.72018

6. Hassan, F.M., Salman, J.M., Al-Azawey, A.S.N., Al-Ansari, N., Kutsson, S. and Quality, S. 2014. Quantity and Origin of PAHs (Polycyclic Aromatic Hydrocarbons) in Lotic Ecosystem of Al-Hilla River, Iraq. Journal of Civil Engineering and Agriculture. 8(8): 1026-1038. https://doi.org /10.17265/1934-7359/2014.08.010

7. Salman, J.M., Al-Azawey, A.S.N. and Hassan, F.M. 2014. The Study of Pollution of PAHs (Polycyclic Aromatic Hydrocarbons) in Al-Hilla River, Iraq by Using Bioindicator Freshwater Crab (Sesarma boulengeri Calman). J. Life Science, 8(4): 351-357. 
8. Al-Azawey, A.N., Salman, J.M. and Hassan, F.M. 2014. Biogeochemical distribution of Poly Aromatic Hydrocarbons (PAHs), PAHs Biogeochemical Accumulation in Environments. LAP Lambert Academic Publishing, Germany.

9. Eisler, R. 1987. Polycyclic Aromatic Hydrocarbon Hazards to Fish, Wildlife and Invertebrates: A Synoptic Review. U.S. Fish and Wildlife Service. Biological Report 85 (1.11).

10. WHO 2003. (World Health Organization), Polynclear Aromatic Hydrocarbons in Drinking Water Background Document for Development of WHO Guidelines for Drinking Water Quality.Geneva, WHO/SDE/WSH/03.04/59).

11. Qiao, M., Wang, C., Huang, S., Wang, D. and Wang, Z. 2006. Composition, Sources, and Potential Toxicological Significance of PAHs in the Surface Sediments of the Meiliang Bay, Taihu Lake, China. Environ. Inter. 32: 28-33.

12. Wick, A.F., Haus, N.W., Sukkariyah, B.F., Hearing, K.C. and Daniels, W.L. 2011. Remediation of PAH-Contaminated Soils and Sediments: A Literature Review. Virginia Polytechnic Institute and State University. Department of Crop and Soil Environmental Sciences. Blacksburg, VA 24061.

13. USEPA, 2008. (United State Environmental Protection Agency), Polycyclic Aromatic Hydrocarbons (PAHs). Fact sheet. Office of Solid Waste. Washington. DC 20460.

14. UBA, 2012. (Umwelt Bundes Amt), Polycyclic Aromatic Hydrocarbons: Harmful to the Environment, Toxic, Inevitable German Federal Environment Agency. Germany.

15. Malhat, F.M., Nasr, I.N. and Arief, A.H. 2010. Polycyclic Aromatic Hydrocarbons (PAHs) in Aquatic Environment at El Menofiya Governorate, Egypt. Journal of Applied Sciences Research. 6(1): $13-21$.

16. Kafilzadeh, F., Shiva, A.H. and Malekpour, R. 2011. Determination of Polycyclic Aromatic Hydrocarbons (PAHs). In Water and Sediments of the Kor River, Iran. MEJSR, 10(1): 1-7.

17. Zhang, Z.L., Hong, H.S., Zhou, J.L. and Yu, G. 2004. Phase Association of Polycyclic Aromatic Hydrocarbons in the Minjiang River Estuary, China. The Science of the Total Environment. 323: $71-86$.

18. Yu, Y., Xu, J., Wang, P. Sun, H. and Dai, S. 2009. Sediment-Pore Water Partition of Polycyclic Aromatic Hydrocarbons (PAHs) from Lanzhou Reach of Yellow River, China. Journal of Hazardous Materials, 165(2009): 494-500.

19. Md. S. Elias, Ab., Wood, K., Hashim, Z., Siong, W.B., M.S. Hamzah, M.S., Abed-Rahman, S., Salim, N.AA.and Talib, A. 2007. Polycyclic Aromatic Hydrocarbon (PAH) Contamination in the Sediment of East Coast Peninsular Malaysia. The Malaysian Journal of Analytical Sciences, 11(1): 70-75.

20. Ibrahim, S.A.R. and Al-Shammaa, A.M. 2012. Hydrochemistry of Shallow Groundwater in Western Karbala City Central Part of Iraq. Iraqi Bulletin of Geology and Mining, 8(3): 91-107.

21. Nasser, H.J. and Kadhim, N.K. 2011. Geographical Analysis of Food Security for Karbala Province during 2011. Al-Batith Journal (Special issue of the $1^{\text {st }}$. Conference of Karbala University), 2012. 563-594 (In Arabic). Available at https://www.iasj.net /iasj? func= fulltex $\underline{t} \& \mathrm{aId}=70763$

22. Hassan, F.M., Salman, J.M. and Abdulameer, S.H. 2014. Seasonal Variation of Environmental Properties and Phytoplankton Community in Al-Hussainya River, Holly Karbala, Iraq. MEJ, 1(1): 56-82.

23. UNEP 1989. (United Nations Environmental Program), Comparative Toxicity Test of Water Accommodated Fraction of Oils and Oil Dispersant's to Marine Organisms. Reference methods for marine pollution No. 45, pp.21.

24. Berset, J.D., Ejem, M., Holzer, R. and Lischer, P. 1999. Comparison of Different Drying, Extraction and Detection Techniques for the Determination of Priority Polycyclic Aromatic Hydrocarbons in Background Contaminated Soil Samples. Analytica Chimica Acta. 383(3): (1999) 263-275.

25. Wang, C., Wang, W., He, S., Du, J. and Sun, Z. 2011. Sources and Distribution of Aliphatic and Polycyclic Aromatic Hydrocarbons in Yellow River Delta Nature Reserve, China. Appl. Geochem. 26: $1330-1336$.

26. Sihag, S., Pathak, H. and Jaroli, D.P. 2014. Factors Affecting the Rate of Biodegradation of Polyaromatic Hydrocarbons. International Journal of Pure \& Applied Bioscience, 2(3): 185-202. 
27. El-Mubarak, A.H., Rushdi, A.I., Al-Mutlaq, K.F., Bazeyad, A.Y., Simonich, S.L.M. and Simoneit, B.R.T. 2014. Identification and Source Apportionment of Polycyclic Aromatic Hydrocarbons in Ambient Air Particulate Matter of Riyadh, Saudi Arabia. Environ Sci Pollut Res, Int. 21: 558-567.

28. Sany, S.B.T., Hashim, R., Salleh, A., Rezayi, M., Mehdinia, A. and Safari, O. 2014. Polycyclic Aromatic Hydrocarbons in Coastal Sediment of Klang Strait, Malysia: Distribution Pattern, Risk Assessment and Sources. PLOS ONE 9(4), e94907.

29. Nekhavhambe, Y.J., Ree, T.V. and Fatoki, O.S. 2014. Determination and Distribution of Polycyclic Aromatic Hydrocarbons in Rivers, Surface Runoff, and Sediments in and around Thohoyandou, Limpopo Province, South Africa. Water SA. 40(3): 415-424.

30. Qiu, Y.W., Zhang, G., Liu, G.Q., Guo, L.L., Li, X.D. and Wai, O. 2009. Polycyclic Aromatic Hydrocarbons (PAHs) in the Water Column and Sediment Core of Deep Bay, South China. Estuarine, Coastal and Shelf Science. 83(2009): 60-66.

31. Chen, B., Xuan, X., Zhu, L., Wang, J., Gao, Y., Yang, K., Shen, X. and Lou, B. 2004. Distributions of Polycyclic Aromatic Hydrocarbons in Surface Waters, Sediments and Soils of Hangzhou City, China. Water Research. 38: 3558-3568.

32. Pandey, J.K., Masih, A., Lal, K., Gaur, V.K., Srivastava, P., Tanveer, M.R., Ansari, S.A. and Sharma, S.D. 2013. Determination of Polycyclic Aromatic Hydrocarbons (PAHs) in Gomti River, Lucknow, India. International Journal of Research in Engineering and Bioscience, 1(Special Issue 1), 44-56.

33. ATSDR 1995. (Agency for Toxic Substances and Disease Registry), Toxicological Profile for Polycyclic Aromatic Hydrocarbons. Department of Health and Human Services. Public Health services. Atlanta, GA. U.S.

34. Tiganus, D., Coatu, V., Lazar, L., Arias, A. and Spinu, A.D. 2013. Identification of the Sources of Polycyclic Aromatic Hydrocarbons in Sediments from the Romanian Black Sea Sector. Cercetari Marine. 43: 187-196. 